\title{
PENGARUH OBJEK WISATA TASIKRIA TERHADAP PERUBAHAN SOSIAL MASYARAKAT DI DESA MOKUPA KECAMATAN TOMBARIRI
}

\author{
Romelin M. Waha \\ Charles R. Ngangi \\ Ellen G. Tangkere
}

\begin{abstract}
The objective of this research is to know the effect of social change especially attitude and social value to the decrease of Tasikria tourism object at Mokupa Village Tombariri Dictrict.The collecting has been conducted for one year, from December, 2014 to December, 2015. The obtained data are primary and decundary data. The primary data are obtained directly from the government at Mokupa Village, Tombariri Sub-Disctrit. The sampling uses purposive sampling chosen at Mokupa Village involving village society such as teacher, government employee, To know the effect of social change especially attitude, it uses Likert Scale Analysis. The research result showed that the effect of social change to tourism object at Mokupa Village Tombariri Sub-Dictrict was high based on attitude and social value of local society. *jnkd*
\end{abstract}

Keywords : tourism object, social change, Tasikria, North Sulawesi

\section{ABSTRAK}

Penelitian ini bertujuan untuk mengetahui pengaruh perubahan sosial khususnya sikap dan nilai sosial terhadap menurunnya objek wisata Tasikria di Desa Mokupa, Kecamatan Tombariri. Pengumpulan data dilakukan selama satu tahun, sejak bulan Desember 2014 hingga bulan Desember 2015. Data yang diperoleh adalah data primer dan sekunder. Data primer diperoleh secara langsung melalui pemerintah yang ada di Desa Mokupa Kecamatan Tombariri. Pengambilan sampel menggunakan Purposive Sampling atau secara sengaja, dipilih di Desa Mokupa Kecamatan Tombariri melibatkan masyarakat desa dari profesi Guru, PNS, Wira Swasta, tukang, pelajar dan ibu rumah tangga. Untuk mengetahui pengaruh perubahan sosial khususnya sikap maka digunakan analisis Skala Likert Hasil Penelitian menunjukkan bahwa tingginya pengaruh perubahan sosial terhadap objek wisata di Desa Mokupa Kecamatan Tombariri adalah tinggi dilihat dari sikap dan nilai sosial dari masyarakat setempat.

Kata Kunci : obyek wisata, perubahan sosial, Tasikria, Sulawesi Utara

\section{PENDAHULUAN}

\section{Latar Belakang}

Indonesia adalah Negara kepulauan yang kaya akan objek wisata yang tersebar dari Sabang sampai Merauke. Perkembangan pariwisata di Indonesia mengalami kemajuan yang pesat sejak pemerintah memutuskan untuk mengandalkan sektor pariwisata. Keberadaan sektor pariwisata mulai mendapat perhatian pemerintah baik pusat maupun daerah karena dianggap mampu berperan dalam proses pembangunan ekonomi yaitu sebagai motor penggerak pembangunan ekonomi. (Soebagyo, 2012). Perhatian pemerintah terhadap sektor pariwisata diwujudkan dalam berbagai kebijakan pemerintah, salah satunya adalah Rencana Pembangunan Jangka Menengah (RPJM) Tahun 2004 - 2009, menjelaskan bahwa salah satu sasaran untuk meningkatkan sektor non-migas adalah dengan meningkatkan kontribusi pariwisata dalam perolehan devisa sehingga sektor pariwisata diharapkan mampu menjadi salah satu penghasilan besar. Berdasarkan hal 
tersebut, maka kebijakan pembangunan kepariwisataan diarahkan untuk meningkatkan efektifitas pemasaran melalui kegiatan promosi dan pengembangan produk-produk wisata serta meningkatkan sinergi dalam jasa pelayanan pariwisata. Dalam pengembangan ekonomi, sosial dan budaya di Daerah pengembangan sektor pariwisata memiliki pengaruh positif bagi pertumbuhan ekonomi daerah. Selain itu sektor pariwisata dapat membantu pelestarian nilai dan budaya lokal, serta berpotensi menjembatani perbedaan sosial budaya dan kesenjangan ekonomi.

Undang-undang tentang kepariwisataan No. 9 tahun 1990 yaitu salah satu tujuan penyelenggaraan kepariwisataan, adalah untuk meningkatkan pendapatan daerah dalam rangka meningkatkan kesejahteraan dan kemakmuran rakyat, juga memperluas serta memberikan kesempatan berusaha dan lapangan kerja untuk mendorong pembangunan daerah.

Perubahan sosial terjadi karena adanya perubahan dalam unsur-unsur yang mempertahankan keseimbangan masyarakat seperti misalnya perubahan dalam unsur-unsur geografis, biologis, ekonomi, atau kebudayaan. Beberapa sosiolog berpendapat bahwa ada kondisikondisi sosial primer yang menyebabkan terjadinya perubahan-perubahan pada aspek-aspek kehidupan sosial lainnya.

Perubahan sosial adalah segala perubahan-perubahan pada lembagalembaga kemasyarakatan di dalam suatu masyarakat yang mempengaruhi sistem sosialnya, termasuk didalamnya nilai-nilai, sikap dan pola perilaku diantara kelompokkelompok dalam masyarakat (Soemardjan 2000).

Perubahan sosial ini khususya perubahan sikap dan nilai terjadi juga pada masyarakat di daerah pariwisata yang merupakan bagian paling peka dengan segala irama perubahan yang pada dasarnya mereka menginginkan kepuasan, mudah diserap, bersifat ekonomis, praktis ataupun modern. (Anonim,2009)
Hal ini terjadi pada masyarakat dan pemerintah di Desa Mokupa karena akibat perubahan social sehingga masyarakat yang sebagian pekerjaanya ialah pedagang dan pengelolah kawasan objek wisata, kini tidak bekerja lagi, ada pula yang beralih profesi, dan kurangnya modal juga menjadi alasan untuk tidak mengelola objek wisata sehingga objek wisata yang dulunya berkembang menjadi menurun dan tidak ramai lagi karena tidak dimanfaatkan atau tidak di olah lagi. Padahal dulunya objek wisata Tasikria menjadi suatu kebanggan masyarakat Desa Mokupa. Namun semuanya berubah ketika terjadi perubahan sosial dalam masyarakat. Akibatnya keindahan pantai di Tasikria yang dulunya merupakan salah satu sumber penghasilan masyarakat Desa Mokupa kini mulai tidak Nampak lagi. Sampai saat ini lamanya objek wisata Tasikria tidak di olah sudah sekitar 10 tahun.

Objek wisata yang tidak di olah yang dimaksud yaitu kawasan pantai Tasikria yang terletak di Desa Mokupa, Kecamatan Tombariri, tepatnya di daerah mudah di jangkau, di jalan trans Sulawesi. Hanya pada objek wisatanya, yang bersebelahan dengan Tasikria resort. Dibiarkan begitu saja dan di tumbuhi rumput dan tanaman lainnya bertumbuh sendiri tanpa campur tangan manusia. Dalam hal ini dilihat dari 10 tahun terakhir.

Tidak dikelolanya suatu objek wisata, sebenarnya menjadi suatu masalah dalam dunia pariwisata, karena semakin banyak objek wisata yang tidak dikelola dengan baik maka semakin sedikit jumlah wisatawan (tourist) yang berkunjung dan berkurangnya popularitas Desa dan kawasan pariwisata tersebut. Karena itu untuk terus mempertahankan "Negara Pariwisata" maka di anggap penting untuk mengetahui pengaruh perubahan sosial terhadap objek wisata.

\section{Rumusan Masalah}

Berdasarkan latar belakang yang telah diuraikan dan dengan konteks yang terkait dengan penelitian ini adalah Apakah adanya perubahan sosial / sikap dan nilai sosial berpengaruh pada perkembangan objek wisata Tasikria? 


\section{Tujuan Penelitian}

Mengetahui pengaruh perubahan sosial khususnya sikap dan nilai sosial terhadap perkembangan objek wisata Tasikria.

\section{'Manfaat Penelitian}

Penelitian ini diharapkan dapat menjadi bahan acuan bagi para pemerintah sebagai masukan terutama dalam pengembangan pariwisata. Penelitian ini di harapkan memberikan manfaat dalam menambah tulisan ilmiah atau referensi dalam pengembangan konsep-konsep teori-teori terutama pada bentuk objek wisata terhadap perubahan sosial.

\section{METODE PENELITIAN}

\section{Lokasi dan Waktu Penelitian}

Penelitan dilaksanakan di Desa Mokupa Kecamatan Tombariri. Selama satu tahun yaitu Desember 2014 sampai Desember 2015, mulai dari persiapan, pengambilan data, sampai pada penyusunan laporan penelitian.

\section{Metode Penelitian}

Penelitian ini menggunakan sumber data dari data primer dan sekunder. Pengumpulan data primer dilakukan melalui wawancara langsung dengan responden yang melibatkan masyarakat, menggunakan daftar pertanyaan yang sudah dipersiapkan atau kuesioner. Sedangkan data sekunder diperoleh dari pemerintah Desa Mokupa kecamatan Tombariri.

\section{Metode Pengambilan Sampel}

Melalui teknik pemilihan responden, responden yang dipilih adalah masyarakat Desa Mokupa. Dengan menggunakan Purposive Sampling atau secara sengaja, dipilih di Desa Mokupa, Kecamatan Tombariri melibatkan masyarakat desa dari profesi Guru, PNS, Wira Swasta, tukang, pelajar dan ibu rumah tangga. dengan seluruh populasi 3000 orang dan responden sebanyak 65 orang di tentukan dalam rumus populasi.

\section{Konsep Pengukuran Variabel}

Variabel-variabel yang dikaji dalam penelitian ini adalah:

1. Karakteristik Responden
a. Umur (Tahun)
b. Tingkat pendidikan (SD, SMP, SMA sederajat)
c. Pekerjaan, dilihat dari profesi responden

2. Menurut Anonim 2009, Perubahan Sosial dilihat dari sikap dan nilai sosial masyarakat Desa Mokupa terhadap objek wisata Tasikria. Pengukuran dilakukan dengan menggunakan skor dilihat dari aspek pikiran (Kognitif), perasaan (Afektif), dan kecenderungan bertindak (Konasi).

1) Kognitif yaitu menunjukan aspek pikiran seseorang tentang :

a. Mencari tahu penyebab mengapa objek wisata tidak di perhatikan

b. Mengetahui alasan mengelola objek wisata

Setuju diberi skor 3

Ragu-ragu skor 2

Tidak setuju diberi skor 1

2) Afektif yaitu menunjukan perasaan sesorang tentang :

a. Merasa tidak perlu mengelola objek wisata Tasikria

b. Merasa perlu mengelola objek wisata

Setuju diberi skor 3

Ragu-ragu skor 2

Tidak setuju diberi skor $\quad 1$

3) Konasi yaitu dimana adanya kecenderungan seseorang untuk bertindak:

a. Kecenderungan untuk mengelola objek wisata

b. Kecenderungan untuk tidak mengelola

Setuju diberi skor 3

Ragu-ragu skor 2

Tidak setuju diberi skor $\quad 1$

3. Nilai sosial yaitu nilai yang baik yang dianut oleh suatu masyarakat ketika melihat sarana objek wisata tidak diolah dan bernilai buruk, disajikan dalam bentuk deskriptif. 


\section{Analisis Data}

Data yang digunakan dalam penelitian ini akan di uji menggunakan analisis secara deskriptif dalam bentuk tabel dan angka. Metode dasar yang dipakai dalam penelitian ini metode deskriptif, yaitu suatu metode yang memusatkan perhatiannya pada pemecahan masalah, data yang dikumpulkan disusun, di analisis dan disimpulkan. Pelaksanaan dari penelitian ini menggunakan metode survei (Surakhmad 1991).

Analisis data juga menggunakan Skala Likert. Menurut Ridwan (2010) Untuk mengukur sikap akan disusun 15 pertanyaan dengan total responden 65 orang. Setiap jawaban dihubungkan dengan bentuk pernyataan atau dukungan sikap yang diungkapkan dengan kata-kata berikut :

$\begin{array}{ll}\text { Setuju } & \text { Skor :3 } \\ \text { Ragu-ragu } & \text { Skor : } 2 \\ \text { Tidak setuju } & \text { Skor : } 1\end{array}$

\section{HASIL DAN PEMBAHASAN}

\section{Deskripsi Wilayah Penelitian}

\section{Batas wilayah}

Desa Mokupa adalah sebuah Desa yang terletak di wilayah Kecamatan Tombariri, Kabupaten Minahasa, Provinsi Sulawesi Utara. Terdiri dari dua belas jaga atau dusun dengan batas wilayah:

Sebelah Utara : Desa Tateli

Sebelah Timur : Desa Koha dan Agotey

Sebelah Selatan: Desa Tambala Tanahwangko Sebelah Barat :Daerah Pesisir Pantai Tasikria

\section{Karakteristik Responden}

\section{Umur Responden}

Tingkat umur mempengaruhi kemampuan seseorang dalam melakukan aktivitas maupun konsep berpikir. Responden yang berumur mudah tentunya memiliki kondisi fisik lebih kuat dibandingkan dengan responden yang berumur tua. Komposisi umur responden dalam penelitian ini disajikan dalam Tabel 1.
Tabel 1. Karakteristik Responden berdasarkan Umur (Tahun)

\begin{tabular}{lcc}
\hline $\begin{array}{c}\text { Umur } \\
\text { (Tahun) }\end{array}$ & Jumlah & $\begin{array}{c}\text { Persentase } \\
(\boldsymbol{\%})\end{array}$ \\
\hline $17-27$ & 3 & 4,62 \\
$28-38$ & 26 & 40 \\
$39-49$ & 22 & 33,84 \\
$50-60$ & 10 & 15,39 \\
$60>$ & 4 & 6,15 \\
\hline
\end{tabular}

\begin{tabular}{lcc}
\hline Jumlah & $\mathbf{6 5}$ & $\mathbf{1 0 0}$ \\
\hline Sumber : Diolah dari data & primer, 2015
\end{tabular}

Tabel 1 menunjukkan bahwa jumlah responden terbanyak berada pada interval umur 28-38 tahun, dan selanjutnya pada interval umur 39 - 49 tahun, dan yang paling sedikit responden yang berada pada interval umur 17 - 27 tahun.

\section{Tingkat Pendidikan Responden}

Tingkah laku individu atau seseorang sangat mempengaruhi oleh pendidikan yang telah dicapai. Begitu juga pada masyarakat Desa Mokupa, tingkat pendidikan akan mempengaruhi masyarakat tidak mengelola objek wisata.

Tabel 2. Karakteristik Responden Berdasarkan Tingkat pendidikan (SD, SMP, SMA sederajat)

\begin{tabular}{lcc}
\hline $\begin{array}{c}\text { Tingkat } \\
\text { pendidikan }\end{array}$ & Jumlah & $\begin{array}{c}\text { Persentase } \\
(\mathbf{\%})\end{array}$ \\
\hline SD & 4 & 6,15 \\
SMP & 9 & 13,84 \\
SMA & 14 & 21,53 \\
D3 & 7 & 10,76 \\
S1 & 29 & 44,61 \\
S2 & 2 & 3,1 \\
\hline Jumlah & $\mathbf{6 5}$ & $\mathbf{1 0 0}$ \\
\hline
\end{tabular}

Sumber : Diolah dari data primer, 2015

Tabel 2 menunjukkan tingkat pendidikan yang dimiliki responden. Data tingkat pendidikan responden yang paling banyak yaitu S1 sebanyak 29 responden $(44,61 \%)$. Sedangkan tingkat SMA sebanyak 14 responden $(21,53 \%)$, tingkat SMP se- 
banyak 9 responden $(13,84)$, D3 Sebanyak 7 responden $(10,76 \%)$, tingkat SD hanya 4 responden dan tingkat pendidikan S2 paling sedikit yaitu 2 responden $(3,1 \%)$.

\section{Pekerjaan Responden}

Jenis Pekerjaan sangat mempengaruhi sikap seseorang terhadap obyek wisata. Karena ketika seseorang sudah menemukan pekerjaan yang tepat dengat tingkat pendapatan yang cukup atau lebih untuk memenuhi kebutuhan keluarga, maka ia akan fokus dengan pe-kerjaan dan hal ini mempengaruhi sesorang untuk mengelola objek wisata.

Tabel 3. Karakteristik Responden berdasarkan Pekerjaan, dilihat dari profesi responden

\begin{tabular}{lcc}
\hline Pekerjaan & Jumlah & $\begin{array}{c}\text { Persen- } \\
\text { tase (\%) }\end{array}$ \\
\hline Pegawai Negeri Sipil & 21 & 32,3 \\
Karyawan swasta & 21 & 32,3 \\
Wiraswasta & 9 & 13,9 \\
Tukang ojek & 8 & 12,3 \\
Ibu Rumah Tangga & 6 & 9,2 \\
\hline Jumlah & $\mathbf{6 5}$ & $\mathbf{1 0 0}$ \\
\hline
\end{tabular}

Sumber : Diolah dari data primer, 2015

Tabel 3 menunjukkan jenis pekerjaan responden masyarakat yang dijadikan sampel dalam penelitian. Tabel 3 menunjukkan bahwa dalam penelitian ini terdapat 5 kategori jenis pekerjaan dari responden, yaitu pegawai negeri sipil, karyawan swasta, wiraswasta, tukang ojek, dan Ibu rumah tangga. Kategori pegawai negeri sipil dan karyawan merupakan jenis pekerjaan terbanyak dari responden yaitu masing-masing sebanyak $32,3 \%$ atau sebanyak 21 orang. Sedangkan jenis pekerjaan yang paling sedikit yaitu wiraswasta, pensiunan dan ibu rumahtangga. Hal ini menunjukkan bahwa kebanyakan yang tidak peduli pada objek wisata sehingga tidak mengelola yang mempunyai pekerjaan sebagai pegawai negeri sipil dan karyawan swasta. Jenis pekerjaan resonden ada beberapa yang dulunya pedagan di daerah objek wisata Tasikria tapi beralih profesi, ada yang memilih hanya menjadi ibu rumah tangga, ada yang beralih profesi sebagai tukang ojek dan ada juga sudah menjadi karyawan swasta.

\section{Analisis Data Skala Likert}

Dengan cara perhitungan skor masingmasing pertanyaan:

Jumlah Skor Tiap Kriterium = Capaian Skor $\mathrm{X}$ Jumlah Responden

Untuk:

$$
\begin{aligned}
& \mathrm{S} 1=3 \times 65=195 \\
& \mathrm{~S} 2=2 \times 65=130 \\
& \mathrm{~S} 3=1 \times 65=65
\end{aligned}
$$

Jumlah skor idela untuk setiap pernyataan (skor tinggi) $=195$

Jumlah skor rendah $=65$

Interprestasi nilai:

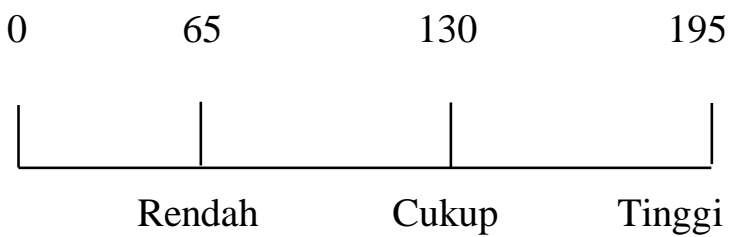

Cara perhitungan skor keseluruhan untuk mengetahui sikap

Jumlah skor seluruh kriterium = Capaian Jumlah skor $\mathrm{X}$ Jumlah Responden $\mathrm{X}$ Instrumen Pertanyaan

Untuk :

$\mathrm{S} 3=3 \times 65 \times 15=2.925$

$\mathrm{S} 2=2 \times 65 \times 15=1.950$

$\mathrm{S} 1=1 \times 65 \times 915=975$

Jumlah skor ideal untuk keseluruhan pernyataan $=2.925$ (Tinggi)

Jumlah skor terendah $=975$ (Rendah)

Dengan interprestasi :

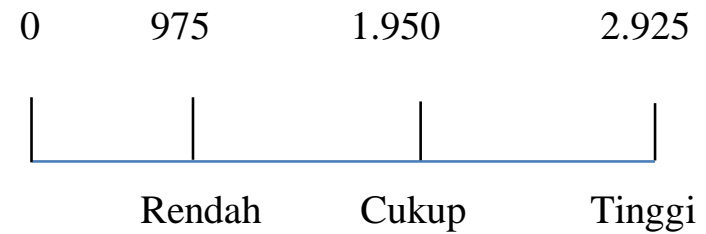

Analisis data yang digunakan merupakan analisis deskriptif yang dianalisis dengan menggunakan skala pengukuran Likert Scale dimana menurut Ridwan (2010) adalah sebagai berikut : 
Tingkat Sikap $=\frac{\text { Jumlah } \text { skor hasil pengumpulan data }}{\text { Jumlah skor ideal }(\text { tertinggi })} \mathrm{x} 100 \%$

Dengan interprestasi :

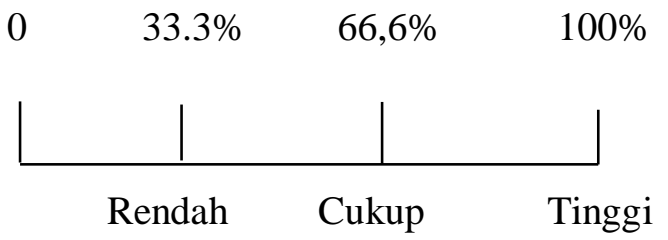

Keterangan Kriteria :

Angka 0\%-33,3\% = Rendah

Angka 33,4\%-66,6\% = Cukup

Angka $66,7 \%-100 \%=$ Tinggi

\section{Perubahan Sosial \\ Sikap Responden Aspek Kognitif (Pikiran)}

Istilah "Cognitive" berasal dari kata cognition artinya adalah pengertian, mengerti. Kognitif adalah proses yang terjadi secara internal di dalam pusat susunan saraf pada waktu manusia sedang berpikir (Jamaris 2006). Dalam perkembangan selanjutnya, kemudian istilah kognitif ini menjadi populer sebagai salah satu wilayah psikologi manusia / satu konsep umum yang mencakup semua bentuk pengenalan yang meliputi setiap perilaku mental yang berhubungan dengan masalah pemahaman, memperhatikan, memberikan, menyangka, pertimbangan, pengolahan informasi, pemecahan masalah, kesengajaan, pertimbangan, membayangkan, memperkirakan, berpikir dan keyakinan.

\section{Semakin berkurangnya masyarakat yang bekerja di kawasan objek wisata}

Profesi Sebagai pekerja di daerah objek wisata di Desa Mokupa terlihat menurun. Menjadi seorang pedagang, tukang parkir, jaga post masuk dan lain-lain bukan lagi suatu impian, dan itu terbukti ketika semakin berkurangnya masyarakat yang berprofesi dari bagian pengolah objek wisata. Dapat di lihat pada Tabel 4.

Hasil penelitian ini menunjukkan bahwa 90,8\% responden (59 orang) setuju dengan pernyataan semakin berkurangnya masyarakat yang bekerja di kawasan objek wisata. Sedangkan sisanya sebanyak 9,2\% responden (6 orang) masih ragu-ragu dengan pernyataan tersebut. Total skor yang diperoleh dari 65 responden pada indicator pernyataan nomor 1 ini adalah sebesar 189. Angka indeks sikap mengenai pernyataan 1 yaitu: 189/195 x $100 \%=96,92 \%$, sehingga interpretasi nilainya tergolong tinggi karena masyarakat Desa Mokupa banyak yang ber-profesi sebagai pegawai negeri, karyawan swasta, tukang dan pekerjaan lainnya.

Alih profesi merupakan salah satu penyebab menurunnya pengolahan objek wisata

Salah satu penyebab tidak di olahnya objek wisata yaitu karena alih profesi, dimana masyarakat berpikir bahwa dengan alih profesi misalnya dari pedagang menjadi tukang ojek, atau pekerjaan lainnya yang lebih menguntungkan. Sikap masyarakat terhadap pernyataan ini di tunjukkan pada Tabel

5. Hasil penelitian ini menunjukkan bahwa $87,7 \%$ responden (57 orang) setuju kalau ternyata alih profesi me-rupakan salah satu penyebab tidak di olahnya objek wisata.

Tabel 4. Semakin berkurangnya masyarakat yang bekerja di kawasan objek wisata

\begin{tabular}{lcccc}
\hline $\begin{array}{c}\text { Jawaban } \\
\text { Alternatif }\end{array}$ & $\begin{array}{c}\text { Alternatif } \\
\text { Skor }\end{array}$ & $\begin{array}{c}\text { Jumlah } \\
\text { Responden }\end{array}$ & $\begin{array}{c}\text { Persentase } \\
\text { Responden }\end{array}$ & $\begin{array}{c}\text { Total Skor } \\
(\%)\end{array}$ \\
\hline Setuju & 3 & 59 & 90,8 & 177 \\
Ragu-ragu & 2 & 6 & 9,2 & 12 \\
Tidak setuju & 1 & - & - & - \\
\hline \multicolumn{1}{c}{ Total } & & $\mathbf{6 5}$ & $\mathbf{1 0 0}$ & $\mathbf{1 8 9}$ \\
\hline Sumber $:$ Diolah dari data primer, 2015 & & &
\end{tabular}

Sumber : Diolah dari data primer, 2015 
Sedangkan $12,3 \%$ responden ( 8 orang) menjawab ragu-ragu dengan pernyataan ini. Total skor yang di proleh daro 65 responden pada pernyataan nomor 2 ini adalah sebesar 187. Angka Indeks sikap mengenai pernyataan 2 yaitu : 187/195 x 100\% $=95,9 \%$ sehingga interpretasi nilainya tergolong tinggi karena masyarakat merasa bahwa pekerjaan lain bisa mencakup kebutuhan hidup yang semakin mahal.

Pekerjaan tetap sebagai karyawan / pegawai menyebabkan kurangnya waktu luang untuk mengelola objek wisata

Salah satu alasan tidak lagi mengelola objek wisata yaitu karena kesibukkan dengan pekerjaan tetap. Misalnya responden yang berprofesi sebagai karyawan swasta yang memilih objekwisata tidak di olah karena pekerjaan menetap. Dan sikap masyarakat terhadap pernyataan ini di tunjukkan dalam Tabel 6.

Hasil Penelitian ini menunjukkan bahwa $100 \%$ responden (65 orang) setuju karena pekerjaan tetap menyebabkan kurangnya waktu masyarakat untuk mengelola objek wisata. total skor yang diperoleh dari 65 responden pada pernyataan nomor 3 adalah 195. Angka indeks sikap mengenai pernyataan nomor 3 yaitu : 195/195 x $100=100 \%$ sehingga interpretasi nilainya tergolong tinggi.

\section{Mengelola objek wisata akan memberikan keuntungan bagi} masyarakat Desa Mokupa

Dengan mengelola objek wisata pastinya akan mendapat keuntungan bagi masyarakat dan bahkan keuntungan yang lumayan jika ditekuni dengan serius, tapi sebaliknya jika objek wisata hanya dibiarkan.

Pemilik lahan cenderung memilih pekerjaan sebagai karyawan / pegawai dibandingkan mengelola objek wisata

Menjadi pengelolah objek wisata contohnya berdagang, tukang parkir dan lain-lain bukan lagi pilihan bagi generasi mudah. Lebih memilih menjadi karyawan / pegawai dibanding hanya untuk mengelola objek wisata. Sikap masyarakat terhadap pernyataan ini dapat dilihat pada Tabel 8.

Tabel 5. Alih profesi merupakan salah satu penyebab menurunnya pengolahan objek wisata

\begin{tabular}{|c|c|c|c|c|}
\hline $\begin{array}{c}\text { Jawaban } \\
\text { Alternatif }\end{array}$ & $\begin{array}{l}\text { Alternatif } \\
\text { Skor }\end{array}$ & $\begin{array}{c}\text { Jumlah } \\
\text { Responden }\end{array}$ & $\begin{array}{l}\text { Persentase } \\
\text { Responden }\end{array}$ & $\begin{array}{c}\text { Total Skor } \\
(\%)\end{array}$ \\
\hline Setuju & 3 & 57 & 87,7 & 171 \\
\hline Ragu-ragu & 2 & 8 & 12,3 & 16 \\
\hline Tidak setuju & 1 & - & - & - \\
\hline Total & & 65 & 100 & 187 \\
\hline
\end{tabular}

Tabel 6. Pekerjaan tetap sebagai karyawan / pegawai menyebabkan kurangnya waktu luang untuk mengelola objek wisata

\begin{tabular}{lcccc}
\hline $\begin{array}{c}\text { Jawaban } \\
\text { Alternatif }\end{array}$ & $\begin{array}{c}\text { Alternatif } \\
\text { Skor }\end{array}$ & Jumlah Responden & $\begin{array}{c}\text { Persentase } \\
\text { Responden }\end{array}$ & $\begin{array}{c}\text { Total Skor } \\
(\%)\end{array}$ \\
\hline Setuju & 3 & 65 & 100 & 195 \\
Ragu-ragu & 2 & - & - & - \\
Tidak setuju & 1 & - & - & - \\
\hline Total & & $\mathbf{6 5}$ & $\mathbf{1 0 0}$ & $\mathbf{1 9 5}$ \\
\hline
\end{tabular}

Sumber : Diolah dari data primer, 2015 
Hasil penelitian ini menunjukkan bahwa 95,4\% responden (62 orang) setuju bahwa masyarakat cenderung memilih pekerjaan sebagai karyawan/pegawai dibandingakn mengelola lahan objek wisata. Sedangkan 4,6\% (3 orang) masih ragu-ragu. Total skor adalah 192. Angka indeks sikap mengenai pernyataan nomor 5 yaitu : $192 / 195 \times 100=98,56 \%$ interpretasinya tergolong tinggi.

Tabel 9 menunjukkan bahwa terdapat 5 indikator sikap masyarakat yang diukur dalam aspek kognitif menyatakan bahwa pernyataan 3 adalah indeks sikap tertinggi. $100 \%$ interpretasi tinggi. Sedangkan pernyataan 1 mendapat indeks sikap 95,92\%, pernyataan 2 mendapat indeks sikap $95,9 \%$, pernyataan 5 indeks sikap 98,46\% dan 4 indeks sikap 88,71\%. Semuanya mencapai interpretasi tinggi karena di atas 66,6\%.

Hasil penelitian ini menunjukkan bahwa semua $46 \%$ responden setuju ketika objek wisata akan memberikan keuntungan bagi masyarakat, dan $52,3 \%$ ragu-ragu. karena mengelola objek wisata tidak selalu memberikan keuntungan tergantung musim dan iklim. Total skor pernyataan nomor 4 ini adalah 159. Angka indeks sikap yaitu : $159 / 195 \times 100=81,53 \%$ tergolong tinggi maka objek wisata tidak biasa mendapat penghasilan apa-apa. Sikap masyarakat terhadap pernyataan ini ditunjukkan pada Tabel 7. Tabel 7. Mengelola objek wisata akan memberikan keuntungan bagi masyarakat Desa
Mokupa

\begin{tabular}{lcccc}
\hline \multicolumn{1}{c}{$\begin{array}{c}\text { Jawaban } \\
\text { Alternatif }\end{array}$} & $\begin{array}{c}\text { Alternatif } \\
\text { Skor }\end{array}$ & Jumlah Responden & $\begin{array}{c}\text { Persentase } \\
\text { Responden }\end{array}$ & $\begin{array}{c}\text { Total Skor } \\
(\%)\end{array}$ \\
\hline Setuju & 3 & 30 & 46,2 & 90 \\
Ragu-ragu & 2 & 34 & 52,3 & 68 \\
Tidak setuju & 1 & 1 & 1,5 & 1 \\
\hline \multicolumn{1}{c}{ Total } & & $\mathbf{6 5}$ & $\mathbf{1 0 0}$ & $\mathbf{1 5 9}$ \\
\hline
\end{tabular}

Sumber : Diolah dari data primer, 2015

Tabel 8. Masyarakat cenderung memilih pekerjaan sebagai karyawan / pegawai dibandingkan mengelola objek wisata

\begin{tabular}{lcccc}
\hline \multicolumn{1}{c}{$\begin{array}{c}\text { Jawaban } \\
\text { Alternatif }\end{array}$} & $\begin{array}{c}\text { Alternatif } \\
\text { Skor }\end{array}$ & Jumlah Responden & $\begin{array}{c}\text { Persentase } \\
\text { Responden }\end{array}$ & $\begin{array}{c}\text { Total } \\
\text { Skor } \\
(\%)\end{array}$ \\
\hline Setuju & 3 & 62 & 95,4 & 186 \\
Ragu-ragu & 2 & 3 & 4,6 & 6 \\
Tidak setuju & 1 & - & - & - \\
\hline \multicolumn{1}{c}{ Total } & & $\mathbf{6 5}$ & $\mathbf{1 0 0}$ & $\mathbf{1 9 2}$ \\
\hline
\end{tabular}

Sumber : Diolah dari data primer, 2015 
Rekapitulasi Indeks Sikap Masyarakat dari Aspek Kognitif

Tabel 9. Rekapitulasi Indeks Sikap Masyarakat dari Aspek Kognitif

\begin{tabular}{|c|c|c|c|c|}
\hline NO & Pernyataan & $\begin{array}{l}\text { Total } \\
\text { Skor }\end{array}$ & $\begin{array}{l}\text { Indeks } \\
\text { Sikap } \\
(\%)\end{array}$ & $\begin{array}{l}\text { Interp } \\
\text { Retasi }\end{array}$ \\
\hline 1 & $\begin{array}{l}\text { Semakin berkurangnya masyarakat yang } \\
\text { bekerja di kawasan objek wisata }\end{array}$ & 189 & 95,92 & Tinggi \\
\hline 2 & $\begin{array}{l}\text { Alih profesi merupakan salah satu } \\
\text { penyebab menurunnya pengolahan objek } \\
\text { wisata }\end{array}$ & 187 & 95,9 & Tinggi \\
\hline 3 & $\begin{array}{l}\text { Pekerjaan tetap sebagai karyawan / } \\
\text { pegawai menyebabkan kurangnya waktu } \\
\text { luang untuk mengelola objek wisata }\end{array}$ & 195 & 100 & Tinggi \\
\hline 4 & $\begin{array}{l}\text { Mengelola objek wisata akan memberikan } \\
\text { keuntungan bagi masyarakat Desa Mokupa }\end{array}$ & 159 & 81,53 & Tinggi \\
\hline 5 & $\begin{array}{l}\text { Masyarakat cenderung memilih pekerjaan } \\
\text { sebagai karyawan / pegawai dibandingkan } \\
\text { mengelola objek wisata }\end{array}$ & 192 & 98,46 & Tinggi \\
\hline
\end{tabular}

Sumber : Diolah dari data primer, 2015

Sikap Responden Aspek Afektif
(perasaan)
Efek ini kadarnya lebih tinggi daripada Efek Kognitif. Tujuan dari komunikasi massa bukan hanya sekedar memberitahu kepada khalayak agar menjadi tahu tentang sesuatu, tetapi lebih dari itu, setelah mengetahui informasi yang diterimanya, khalayak diharapkan dapat merasakannya.

Merasa tidak puas dengan hasil pengolahan objek wisata sehingga objek wisata dibiarka tidak di olah dengan baik

Sikap seseorang dapat dilihat lewat aspek afektif atau perasaan. Salah satunya ketidakpuasan seseorang. Hal ini di tunjukkan pada Tabel 10.

Hal ini menunjukkan bahwa 100\% responden dari (65 orang) setuju bahwa masyarakat merasa tidak puas dengan hasil yang diperoleh dari olahan objek wisata. Total skor 195. Angka indeks sikap nomor 6 yaitu : $195 / 195$ x $100=100 \%$ interpretasi nilai tinggi.

Merasa tidak perlu mengelola objek wisata agar tidak lagi menyediakan modal

Harga bahan pokok semakin naik untuk saat ini. Sebaiknya upaya mencari keuntungan dengan mengelola objek wisata walau hanya sekedar tambahan uang saku. Sikap masyarakat terhadap pernyataan ini di Tabel 11. Hasil penelitian menunjukkan bahwa 46,2 responden (30 orang) setuju dengan pernyataan tersebut. Sedangkan $58,3 \%$ (35 orang) masih ragu-ragu dengan pernyataan tersebut karena mereka sendiri tidak mengelola objek wisata. Total skor 160. Angka indeks sikap nomor 7 yaitu : $160 / 195 \times 100 \%=82,05 \%$. Interpretasi nilai tergolong tinggi. 
Tabel 10. Merasa tidak puas dengan hasil pengolahan objek wisata sehingga objek wisata dibiarkan tidak diolah dengan baik

\begin{tabular}{lcccc}
\hline \multicolumn{1}{c}{$\begin{array}{c}\text { Jawaban } \\
\text { Alternatif }\end{array}$} & $\begin{array}{c}\text { Alternatif } \\
\text { Skor }\end{array}$ & Jumlah Responden & $\begin{array}{c}\text { Persentase } \\
\text { Responden }\end{array}$ & $\begin{array}{c}\text { Total Skor } \\
(\%)\end{array}$ \\
\hline Setuju & 3 & 65 & 100 & 195 \\
Ragu-ragu & 2 & - & - & - \\
Tidak setuju & 1 & - & - & - \\
\hline \multicolumn{1}{c}{ Total } & $\mathbf{6 5}$ & $\mathbf{1 0 0}$ & $\mathbf{1 9 5}$ \\
\hline Sumber : Diolah dari data primer, 2015 &
\end{tabular}

Tabel 11. Merasa tidak perlu mengelola objek wisata agar tidak lagi menyediakan modal

\begin{tabular}{lcccc}
\hline \multicolumn{1}{c}{$\begin{array}{c}\text { Jawaban } \\
\text { Alternatif }\end{array}$} & $\begin{array}{c}\text { Alternatif } \\
\text { Skor }\end{array}$ & Jumlah Responden & $\begin{array}{c}\text { Persentase } \\
\text { Responden }\end{array}$ & $\begin{array}{c}\text { Total Skor } \\
(\boldsymbol{\%})\end{array}$ \\
\hline Setuju & 3 & 30 & 46,2 & 90 \\
Ragu-ragu & 2 & 35 & 58,3 & 70 \\
Tidak setuju & 1 & - & - & - \\
\hline \multicolumn{1}{c}{ Total } & & $\mathbf{6 5}$ & $\mathbf{1 0 0}$ & $\mathbf{1 6 0}$ \\
\hline
\end{tabular}

Sumber : Diolah dari data primer, 2015

Mengelola objek wisata dapat mensejahterakan masyarakat

Kesejahteraan masyarakat bisa didapatkan dengan adanya upaya dan kerja keras dari hasil pengelolaan objek wisata. Sehingga bisa membuka tenaga kerja. Jika objek wisata diolah sebaik mungkin, digunakan sebaik-baiknya maka hasil hasil dari pengolahan itu tidak mengecewakan. Sikap masyarakat dari pernyataan tersebut dilihat di Tabel 12.

Hasil penelitian ini menunjukkan bahwa $84,6 \%$ responden (60 orang) setuju bahwa mengelola objek wisata bisa mensejahterakan masyarakat. Sedangka $15,4 \%$ (10 orang) masih ragu-ragu. Total skor 185 . Angka indeks sikap nomor 8 yaitu : 185/195 x $100=94,87 \%$. Interpretasi nilai tergolong tinggi.
Ingin mendapat hasil yang lebih baik dengan mencari pekerjaan lain

Mendapatkan pekerjaan dengan penghasilan yang banyak menjadu tujuan banyak orang. Termasuk masyarakat Desa Mokupa. Ketika masyarakat merasa hasil dari pengolahan objek wisata sangat sedikit maka ada perasaan ingin mencari pekerjaan lain. Sikap masyarakat dilihat dari pernyataan ditunjukkan pada Tabel 13. Hasil penelitian ini menunjukkan bahwa 94,4 \% responden (62 orang) setuju dengan pernyataan tersebut. Sedangkan 4,6 (3 orang) masih ragu-ragu. Total skor 192. Angka indeks sikap nomor 9 yaitu : $192 / 195 \times 100=98,46 \%$. Interpretasi tergolong tinggi. 
Tabel 12. Mengelola objek wisata dapat mensejahterakan masyarakat

\begin{tabular}{lcccc}
\hline $\begin{array}{c}\text { Jawaban } \\
\text { Alternatif }\end{array}$ & $\begin{array}{c}\text { Alternatif } \\
\text { Skor }\end{array}$ & Jumlah Responden & $\begin{array}{c}\text { Persentase } \\
\text { Responden }\end{array}$ & $\begin{array}{c}\text { Total Skor } \\
(\%)\end{array}$ \\
\hline Setuju & 3 & 55 & 84,6 & 165 \\
Ragu-ragu & 2 & 10 & 15,4 & 20 \\
Tidak setuju & 1 & - & - & - \\
\hline Total & & $\mathbf{6 5}$ & $\mathbf{1 0 0}$ & $\mathbf{1 8 5}$ \\
\hline
\end{tabular}

Sumber : Diolah dari data primer, 2015

Sering mengalami kerugian saat mengelola objek wisata karena pengeluaran lebih besar dari pada hasil yang di dapat.

Resiko saat mengelola objek wisata yaitu ketika mengalami kerugian. Terkadang pengeluaran lebih besar dari penghasilan. Pernyataan tersebut dapat dilihat pada Tabel 14.

Hasil penelitian ini menunjukkan bahwa $92,3 \%$ responden (60 orang) setuju sering mengalami kerugian. Sedangkan 7,7\% (5 orang) masih ragu-ragu. Total skor 190. Angka indeks sikap pernyataan nomor 10 yaitu : $190 / 195 \times 100 \%=98,46 \%$. Interpretasi nilai tergolong tinggi.
Tabel 15 menunjukkan bahwa terdapat 5 indikator sikap masyarakat yang diukur dalam bentuk aspek afektif. Indikator dengan jumlah indeks sikap tertinggi adalah pernyataan nomor 1 yaitu $100 \%$, selanjutnya pernyataan 4 yaitu $98,46 \%$ pernyataan 5 yaitu $97,43 \%$, pernyataan 3 yaitu $95,87 \%$ dan pernyataan $282 \%$. Semuanya tergolong tinggi.

\section{Sikap Responden Aspek Konasi}

Aspek ini menitik-beratkan bukan hanya pada pemerintah tetapi juga masyarakat sebagai wujud dari perencanaan untuk ditindak lanjuti perkembangannya secara tindakan nyata.

Tabel 13. Ingin mendapat hasil yang lebih baik dengan mencari pekerjaan lain

\begin{tabular}{lcccc}
\hline $\begin{array}{c}\text { Jawaban } \\
\text { Alternatif }\end{array}$ & $\begin{array}{c}\text { Alternatif } \\
\text { Skor }\end{array}$ & $\begin{array}{c}\text { Jumlah } \\
\text { Responden }\end{array}$ & $\begin{array}{c}\text { Persentase } \\
\text { Responden }\end{array}$ & $\begin{array}{c}\text { Total Skor } \\
(\mathbf{\%})\end{array}$ \\
\hline Setuju & 3 & 62 & 95,4 & 186 \\
Ragu-ragu & 2 & 3 & 4,6 & 6 \\
Tidak setuju & 1 & - & - & - \\
\hline \multicolumn{1}{c}{ Total } & & $\mathbf{6 5}$ & $\mathbf{1 0 0}$ & $\mathbf{1 9 2}$ \\
\hline Sumber $:$ Diolah dari data primer, 2015 & & &
\end{tabular}

Tabel 14. Sering mengalami kerugian saat mengelola objek wisata karena pengeluaran lebih besar dari pada hasil yang di dapat.

\begin{tabular}{lcccc}
\hline \multicolumn{1}{c}{$\begin{array}{c}\text { Jawaban } \\
\text { Alternatif }\end{array}$} & $\begin{array}{c}\text { Alternatif } \\
\text { Skor }\end{array}$ & $\begin{array}{c}\text { Jumlah } \\
\text { Responden }\end{array}$ & $\begin{array}{c}\text { Persentase } \\
\text { Responden }\end{array}$ & $\begin{array}{c}\text { Total Skor } \\
(\boldsymbol{\%})\end{array}$ \\
\hline Setuju & 3 & 60 & 92,3 & 186 \\
Ragu-ragu & 2 & 5 & 7,7 & 6 \\
Tidak setuju & 1 & - & - & - \\
\hline Total & & $\mathbf{6 5}$ & $\mathbf{1 0 0}$ & $\mathbf{1 9 0}$ \\
\hline
\end{tabular}

Sumber : Diolah dari data primer, 2015 
Tabel 15. Rekapitulasi Jumlah Skor Pengambilan Data, Indeks Sikap, dan Interpretasi Pada Indikator Sikap Masyarakat Aspek Afektif

\begin{tabular}{clccc}
\hline NO & \multicolumn{1}{c}{ Pernyataan } & $\begin{array}{c}\text { Total } \\
\text { Skor }\end{array}$ & $\begin{array}{c}\text { Indeks } \\
\text { Sikap } \\
(\%)\end{array}$ & $\begin{array}{c}\text { Inter- } \\
\text { pretasi }\end{array}$ \\
\hline 1 & $\begin{array}{l}\text { Merasa tidak puas dengan hasil pengolahan } \\
\text { objek wisata sehingga objek wisata } \\
\text { dibiarka tidak di olah dengan baik }\end{array}$ & 195 & 100 & Tinggi \\
2 & $\begin{array}{l}\text { Merasa tidak perlu mengelola objek wisata } \\
\text { agar tidak lagi menyediakan modal }\end{array}$ & 160 & 82,05 & Tinggi \\
3 & $\begin{array}{l}\text { Mengelola objek wisata dapat } \\
\text { mensejahterakan masyarakat }\end{array}$ & 185 & 94,87 & Tinggi \\
4 & $\begin{array}{l}\text { Ingin mendapat hasil yang lebih baik } \\
\text { dengan mencari pekerjaan lain }\end{array}$ & 192 & 98,46 & Tinggi \\
& $\begin{array}{l}\text { Sering mengalami kerugian saat mengelola } \\
\text { objek wisata karena pengeluaran lebih } \\
\text { besar dari pada hasil yang di dapat. }\end{array}$ & 190 & 97,43 & Tinggi \\
\end{tabular}

Sumber : Diolah dari data primer, 2015

Kecenderungan mengelola objek wisata untuk kepentingan keluarga (pendapatan)

Dalam pengolahan objek wisata terdapat beberapa alasan mengapa mengelola objek wisata. Salah satunya karena memenuhi kebutuhan sehari-hari dalam keluarga mencari penghasilan walau hanya seberapa. Sikap masyarakat terhadap pernyataan ini ditunjukkan pada Tabel 16.

Hasil penelitian ini menunjukkan bahwa $46,2 \%$ responden (30 orang) setuju dengan pernyataan tersebut. Sedangkan 58,3\% (35 orang) masih ragu-ragu dengan pernyataan tersebut. Total skor 160 dari 65 responden. Angka indeks sikap mengenai pernyataan nomor 11 yaitu: $160 / 195 \times 100 \%=82,05 \%$. Sehingga interpretasi tergolong tinggi.
Kecenderungan tidak mengelola objek wisata kaarena mahalnya sewa tenaga kerja dan sewa tempat jualan

Kecenderungan tidak mengelola objek wisata salah satunya karena mahalnya sewa tenaga kerja dan sewa tempat berdagang. Biaya tenaga kerja semakin mahal karena tenaga kerja semakin berkurang. Sikap masyarakat terhadap pernyataan ini di tunjukkan dalam Tabel 17.

Hasil penelitian ini menunjukkan bahwa 96,9\% responden (63 orang) setuju dengan pernyataan tersebut. Sedangkan $31,1 \%$ (2 orang) masih ragu-ragu. Total skor adalah 193. Angka indeks sikap mengenai pernyataan nomor 12 yaitu : 193/195 x $100 \%=98,97 \%$. Sehingga interpretasi tergolong tinggi. 
Kecenderungan tidak mengelola objek wisata karena jarak objek wisata dari tempat tinggal

Jarak merupakan salah satu faktor objek wisata tidak diolah. Karena banyak tempat tinggal masyarakat jauh sedikit jauh dari dari kawasan objek wisata. Sikap masyarakat dalam pernyataan ini ditunjukkan pada Tabel 18.

Hasil penelitian ini menyatakan bahwa 90,8\% responden (59 orang) setuju dengan pernyataan tersebut. Sedangkan 9,2\% (6 orang) masih ragu-ragu. Total skor adalah 189. Angka indeks sikap mengenai pernyataan nomor 13 yaitu : 189/195 x 100\% = 96,92\% . Sehingga interpretasi tergolong tinggi.

Kecenderungan mengelola objek wisata untuk mendapat keuntungan

Kecenderungan masyarakat untuk mengelola objek wisata antara lain supaya mendapat keuntungan. Banyak masyarakat yang bisa dikatakan berhasil karena tahu bagaimana mengelola objek wisata agar mendapat keuntungan. Sikap masyarakat terhadap pernyataan ini di tunjukkan dalam Tabel 19.

Tabel 16. Kecenderungan mengelola objek wisata untuk kepentingan keluarga (pendapatan)

\begin{tabular}{ccccc}
\hline $\begin{array}{c}\text { Jawaban } \\
\text { Alternatif }\end{array}$ & $\begin{array}{c}\text { Alternatif } \\
\text { Skor }\end{array}$ & Jumlah Responden & $\begin{array}{c}\text { Persentase } \\
\text { Responden }\end{array}$ & $\begin{array}{c}\text { Total Skor } \\
(\mathbf{\%})\end{array}$ \\
\hline Setuju & 3 & 30 & 46,2 & 90 \\
Ragu-ragu & 2 & 35 & 58,3 & 70 \\
Tidak setuju & 1 & - & - & - \\
\hline Total & & $\mathbf{6 5}$ & $\mathbf{1 0 0}$ & $\mathbf{1 6 0}$ \\
\hline Sumber : Diolah dari data primer, 2015 & & &
\end{tabular}

Tabel 17. Kecenderungan tidak mengelola objek wisata karena mahalnya sewa tenaga kerja dan sewa tempat berdagang

\begin{tabular}{lcccc}
\hline $\begin{array}{c}\text { Jawaban } \\
\text { Alternatif }\end{array}$ & $\begin{array}{c}\text { Alternatif } \\
\text { Skor }\end{array}$ & $\begin{array}{c}\text { Jumlah } \\
\text { Responden }\end{array}$ & $\begin{array}{c}\text { Persentase } \\
\text { Responden }\end{array}$ & $\begin{array}{c}\text { Total Skor } \\
(\boldsymbol{\%})\end{array}$ \\
\hline Setuju & 3 & 63 & 96,9 & 189 \\
Ragu-ragu & 2 & 2 & 3,1 & 4 \\
Tidak setuju & 1 & - & - & - \\
\hline \multicolumn{1}{c}{ Total } & & $\mathbf{6 5}$ & $\mathbf{1 0 0}$ & $\mathbf{1 9 3}$ \\
\hline
\end{tabular}

Sumber : Diolah dari data primer, 2015

Tabel 18. Kecenderungan tidak mengelola objek wisata karena jarak objek wisata dari tempat tinggal

\begin{tabular}{lcccc}
\hline \multicolumn{1}{c}{$\begin{array}{c}\text { Jawaban } \\
\text { Alternatif }\end{array}$} & $\begin{array}{c}\text { Alternatif } \\
\text { Skor }\end{array}$ & $\begin{array}{c}\text { Jumlah } \\
\text { Responden }\end{array}$ & $\begin{array}{c}\text { Persentase } \\
\text { Responden }\end{array}$ & $\begin{array}{c}\text { Total Skor } \\
(\%)\end{array}$ \\
\hline Setuju & 3 & 59 & 90,8 & 177 \\
Ragu-ragu & 2 & 6 & 9,2 & 12 \\
Tidak setuju & 1 & - & - & - \\
\hline \multicolumn{1}{c}{ Total } & & $\mathbf{6 5}$ & $\mathbf{1 0 0}$ & $\mathbf{1 8 9}$ \\
\hline
\end{tabular}

Sumber : Diolah dari data primer, 2015 
Tabel 19. Kecenderungan mengelola objek wisata untuk mendapat keuntungan

\begin{tabular}{lcccc}
\hline $\begin{array}{l}\text { Jawaban } \\
\text { Alternatif }\end{array}$ & $\begin{array}{c}\text { Alternatif } \\
\text { Skor }\end{array}$ & $\begin{array}{c}\text { Jumlah } \\
\text { Responden }\end{array}$ & $\begin{array}{c}\text { Persentase } \\
\text { Responden }\end{array}$ & $\begin{array}{c}\text { Total Skor } \\
(\mathbf{\%})\end{array}$ \\
\hline Setuju & 3 & 31 & 47,7 & 93 \\
Ragu-ragu & 2 & 34 & 52,3 & 68 \\
Tidak setuju & 1 & - & - & - \\
\hline \multicolumn{2}{c}{ Total } & $\mathbf{6 5}$ & $\mathbf{1 0 0}$ & $\mathbf{1 6 1}$ \\
\hline Sumber : Diolah dari data primer, 2015 & &
\end{tabular}

Hasil dari penelitian menunjukkan bahwa 47,4\% responden (31 orang) setuju dengan pernyataan tersebut bahwa banyak yang cenderung mengelola objekwisata untuk mendapat keuntungan. Sedangkan $52,3 \%$ (34 orang) masih ragu-ragu. Total skor 189. Angka indeks sikap mengenai pernyataan nomor 14 yaitu : 161/195 x $100 \%=82,56 \%$. Sehingga interpretasi tergolong tinggi karena masyarakat tahu bahwa pemerintah ingin mengelola objek wisata ingin mendapat keuntungan tanpa memikirkan ketika mengalami kerugian.

Kecenderungan tidak mengola objek wisata karena kondisi fisik / umur yang semakin tua

Kondisi fisik atau umur seringkali menghambat masyarakat untuk mengelola objek wisata. Sikap masyarakat terhadap pernyataan ini akan ditunjukkan pada Tabel 20.
Hasil penelitian ini telah menunjukkan bahwa $40 \%$ (26 orang) setuju bahwa kecenderungan tidak mengelola lahan karena kondisi fisik/umur yang semakin tua, pada pernyataan tersebut. Dan 26 orang lainnya ragu-ragu. Total skor diperoleh dari 65 responden pada pernyataan ini adalah sebesar 143. Angka indeks sikap mengenai pernyataan nomor 15 yaitu : 143/195 x 100\% = 73,33\% . Sehingga interpretasi tergolong tinggi karena berada di atas $66,6 \%$.

Tabel 21 menunjukkan bahwa terdapat 5 indikator sikap masyarakat yang di ukur dalam aspek konasi dimana pernyataan 12 adalah indeks sikap tertinggi, yaitu 98,97\%. Sedangkan pernyataan 13 mendapat indeks sikap $96,92 \%$, pernyataan 14 mendapat indeks sikap 92,30\%. Pernyataan 11 mendapat indeks sikap 90,76\% dan pernyataan 15 mendapat indeks sikap 73,33\%. Dan semuanya mendapat Interpretasi tinggi.

Tabel 20. Kecenderungan tidak mengola objek wisata karena kondisi fisik / umur yang semakin tua

\begin{tabular}{ccccc}
\hline $\begin{array}{c}\text { Jawaban } \\
\text { Alternatif }\end{array}$ & $\begin{array}{c}\text { Alternatif } \\
\text { Skor }\end{array}$ & Jumlah Responden & $\begin{array}{c}\text { Persentase } \\
\text { Responden }\end{array}$ & $\begin{array}{c}\text { Total Skor } \\
(\mathbf{\%})\end{array}$ \\
\hline Setuju & 3 & 26 & 40 & 78 \\
Ragu-ragu & 2 & 26 & 40 & 52 \\
Tidak setuju & 1 & 13 & 20 & - \\
\hline Total & & $\mathbf{6 5}$ & $\mathbf{1 0 0}$ & $\mathbf{1 4 3}$ \\
\hline
\end{tabular}

Sumber : Diolah dari data primer, 2015 


\section{Rekapitulasi Indeks Sikap Masyarakat dari Aspek Konasi}

Tabel 21. Rekapitulasi Jumlah Skor Pengambilan Data, Indeks Sikap, dan Interpretasi pada Indikator Sikap Masyarakat Aspek Konasi

\begin{tabular}{|c|c|c|c|c|}
\hline NO & Pernyataan & $\begin{array}{l}\text { Total } \\
\text { Skor }\end{array}$ & $\begin{array}{l}\text { Indeks } \\
\text { Sikap } \\
(\%)\end{array}$ & $\begin{array}{l}\text { Inter- } \\
\text { pretasi }\end{array}$ \\
\hline 1 & $\begin{array}{l}\text { Kecenderungan mengelola objek wisata } \\
\text { untuk kepentingan keluarga } \\
\text { (pendapatan) }\end{array}$ & 160 & 82,05 & Tinggi \\
\hline 2 & $\begin{array}{l}\text { Kecenderungan tidak mengelola objek } \\
\text { wisata kaarena mahalnya sewa tenaga } \\
\text { kerja dan sewa tempat jualan }\end{array}$ & 193 & 98,97 & Tinggi \\
\hline 3 & $\begin{array}{l}\text { Kecenderungan tidak mengelola objek } \\
\text { wisata karena jarak objek wisata dari } \\
\text { tempat tinggal }\end{array}$ & 189 & 96,92 & Tinggi \\
\hline 4 & $\begin{array}{l}\text { Kecenderungan mengelola objek wisata } \\
\text { untuk mendapat keuntungan }\end{array}$ & 161 & 82,56 & Tinggi \\
\hline 5 & $\begin{array}{l}\text { Kecenderungan tidak mengola objek } \\
\text { wisata karena kondisi fisik / umur yang } \\
\text { semakin tua }\end{array}$ & 143 & 73,33 & Tinggi \\
\hline
\end{tabular}

Sumber : Diolah dari data primer, 2015

Tabel 22 menunjukkan bahwa semua indikator mendapatkan skor pada indeks yang tergolong tinggi (66,7-100). Walaupun pada indikator 15 yakni aspek konasi hanya mendapat 143 namun masih tergolong tinggi. Hal ini menunjukkan bahwa pengaruh perubahan sosial dalam hal ini sikap tergolong tinggi terhadap menurunnya objek wisata Tasikria di Desa Mokupa Kecamatan Tombariri.

Untuk mengetahui letak sikap masyarakat terhadap objek wisata maka perlu dihitung jumlah keseluruhan skor pada setiap kriterium, dimana sesuai hasil penelitian ini skor mencapai 2.752. Pada penelitian ini, jumlah skor ideal (skor tertinggi), yaitu 2.925 (tinggi) dan jumlah skor terendah yaitu 975 (rendah). Berdasarkan data yang dihimpun dari sebanyak 15 instrumen pernyataan yang di ajukan kepada 65 responden, maka diperoleh total skor 2.925, dengan letak indeks ditentukan sebagai berikut :

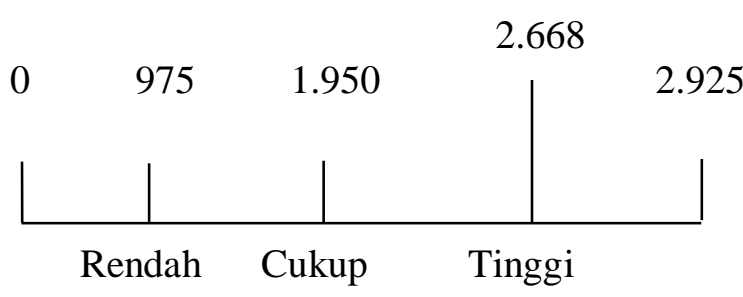

Secara Presentase, angka indeks sikap masyarakat terhadap objek wisata terletak pada :

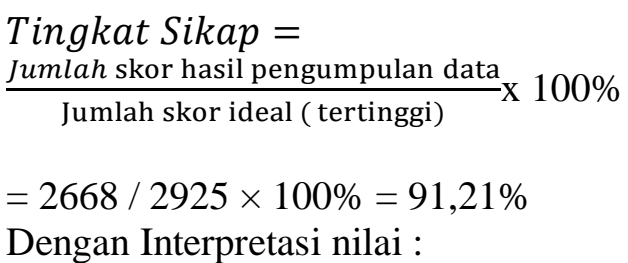




\begin{tabular}{|c|c|c|c|c|}
\hline \multirow{3}{*}{0} & & \multicolumn{2}{|c|}{$91,21 \%$} & Berdasarkan hasil analisis meng- \\
\hline & $33,3 \%$ & $66,6 \%$ & $100 \%$ & gunakan skala likert, maka dapat diketahui \\
\hline & & & & $\begin{array}{l}\text { terhadap objek wisata berada pada titik } \\
91.21 \% \text { dan tergolong tinggi. }\end{array}$ \\
\hline
\end{tabular}

\section{Rekapitulasi Indeks Sikap Pemilik Lahan terhadap Lahan Tidur Pada Masing-Masing Indikator dan Interpretasi Hasil}

Tabel 22. Rekapitulasi Total Skor, Indeks dan Interpretasi Hasil

\begin{tabular}{|c|c|c|c|c|}
\hline No & Pernyataan & $\begin{array}{l}\text { Total } \\
\text { Skor }\end{array}$ & $\begin{array}{l}\text { Indeks } \\
\text { Sikap } \\
(\%)\end{array}$ & $\begin{array}{l}\text { Inter- } \\
\text { pretasi }\end{array}$ \\
\hline 1 & $\begin{array}{l}\text { Semakin berkurangnya masyarakat yang bekerja di } \\
\text { kawasan objek wisata }\end{array}$ & 189 & 95,92 & Tinggi \\
\hline 2 & $\begin{array}{l}\text { Alih profesi merupakan salah satu penyebab } \\
\text { menurunnya pengolahan objek wisata }\end{array}$ & 187 & 95.09 & Tinggi \\
\hline 3 & $\begin{array}{l}\text { Pekerjaan tetap sebagai karyawan / pegawai } \\
\text { menyebabkan kurangnya waktu luang untuk mengelola } \\
\text { objek wisata }\end{array}$ & 195 & 100 & Tinggi \\
\hline 4 & $\begin{array}{l}\text { Mengelola objek wisata akan memberikan keuntungan } \\
\text { bagi masyarakat Desa Mokupa }\end{array}$ & 159 & 81,53 & Tinggi \\
\hline 5 & $\begin{array}{l}\text { Masyarakat cenderung memilih pekerjaan sebagai } \\
\text { karyawan / pegawai dibandingkan mengelola objek } \\
\text { wisata }\end{array}$ & 192 & 98,46 & Tinggi \\
\hline 6 & $\begin{array}{l}\text { Merasa tidak puas dengan hasil pengolahan objek wisata } \\
\text { sehingga objek wisata dibiarka tidak di olah dengan baik }\end{array}$ & 195 & 100 & Tinggi \\
\hline 7 & $\begin{array}{l}\text { Merasa tidak perlu mengelola objek wisata agar tidak } \\
\text { lagi menyediakan modal }\end{array}$ & 160 & 82,05 & Tinggi \\
\hline 8 & $\begin{array}{l}\text { Mengelola objek wisata dapat mensejahterakan } \\
\text { masyarakat }\end{array}$ & 185 & 94,87 & Tinggi \\
\hline 9 & $\begin{array}{l}\text { Ingin mendapat hasil yang lebih baik dengan mencari } \\
\text { pekerjaan lain }\end{array}$ & 192 & 98,46 & Tinggi \\
\hline 10 & $\begin{array}{l}\text { Sering mengalami kerugian saat mengelola objek wisata } \\
\text { karena pengeluaran lebih besar dari pada hasil yang di } \\
\text { dapat. }\end{array}$ & 190 & 97,43 & Tinggi \\
\hline 11 & $\begin{array}{l}\text { Kecenderungan mengelola objek wisata untuk } \\
\text { kepentingan keluarga (pendapatan) }\end{array}$ & 160 & 82,05 & Tinggi \\
\hline 12 & $\begin{array}{l}\text { Kecenderungan tidak mengelola objek wisata kaarena } \\
\text { mahalnya sewa tenaga kerja dan sewa tempat jualan }\end{array}$ & 193 & 98,97 & Tinggi \\
\hline 13 & $\begin{array}{l}\text { Kecenderungan tidak mengola objek wisata karena jarak } \\
\text { objek wisata dari tempat tinggal }\end{array}$ & 189 & 96,92 & Tinggi \\
\hline 14 & $\begin{array}{l}\text { Kecenderungan mengelola objek wisata untuk mendapat } \\
\text { keuntungan }\end{array}$ & 161 & 82,56 & Tinggi \\
\hline 15 & $\begin{array}{l}\text { Kecenderungan tidak mengelola objek wisata karena } \\
\text { kondisi fisik / umur yang semakin tua }\end{array}$ & 143 & 73,33 & Tinggi \\
\hline
\end{tabular}

Sumber : Diolah dari data primer, 2015 


\section{Nilai sosial}

Nilai sosial yang ada masyarakat di Desa Mokupa ternyata mulai menurun. Bukan saja masyarakat tapi pemerintah pada umunya. Karena pandangan mereka terhadap objek wisata mulai berbeda jika dibindangkan dengan 10 tahun terakhir ini. Dulunya jika objek wisata mulai dibiarkan atau tidak diolah, maka masyarakat akan menjadi sorotan dan pembicaraan masyarakat luas sehingga dianggap malas oleh masyarakat lain. Sekarang tidak lagi mersa malu, sehingga tidak mengelola objek wisata sudah menjadi hal yang biasaa.

Hal ini menunjukkan bahwa nilai sosial pemerintah lebih khusus masyarakat Desa Mokupa mulai hilang, kesadaran untuk mengelola objek wisata tidak ada lagi. Desa Mokupa yang dulunya dianggap istimewa atau sesuatu yang berharga bagi masyarakat luas saat ini tidak lagi. Terbukti saat ini dengan adanya objek wisata pantai Tasikria yang tidak ramai lagi karena penurunan drastis.

\section{KESIMPULAN DAN SARAN}

\section{Kesimpulan}

Penelitian ini menunjukkan bahwa perubahan sosial berpengaruh terhadap menurunnya objek wisata pantai Tasikria. Sikap masyarakat yang di ukur dengan skala likert menunjukkan pengaruh sikap kognitif, afektik, dan konasi berada pada titik $91,21 \%$ dan tergolong tinggi. Perubahan sosial dipengaruhi juga oleh faktor umur, tingkat pendidikan dan pekerjaan masyarakat. Menurunnya objek wisata juga di sebabkan karena nilai sosial masyarakat yang semakin menurun, dimana pemerintah mulai malas dan mulai tidak peduli untuk mengelola objek wisata Tasikria.

\section{Saran}

Bagi masyarakat kiranya dapat mengelola kembali objek wisata pantai Tasikria dan menyadari manfaat ketika mengolah objek wisata. Juga perlu adanya sosialisasi dari lembaga pemerintah dalam hal ini melalui dinas pariwisata atau instansi-instansi terkait kepada masyarakat tentang pentingnya mengelola objek wisata pantai dan lebih lagi memupuk nilai-nilai sosial yang ada pada pemerintah terlebih kepada masyarakat tentang bagaimana seharusnya alam ciptaan yang diciptakan kepada manusia untuk diolah, dijaga dan dilindungi.

\section{DAFTAR PUSTAKA}

Emile D, 2001. Teori Bentuk dampak Perubahan Sosial. Gramedia. Jakarta.

Hadinoto, K. 1996. Perencanaan Pengembangan Destinasi Pariwisata. Perdana. Jakarta.

Jamaris M, 2006. Arti luas dari Perubahan Sosisal. Grasindo. Jakarta.

Kusumaningrum, D. 2009. Presepsi Wisatawan Nusantara Terhadap Daya Tarik Wisata Di Kota Palembang. Tesis PS. Magister Kajian Pariwisata. Universitas Gadjah Mada. Yogyakarta.

Marpaung, F. 2009. Strategi Pengembangan Kawasan Sebagai sebuah tujuan Wisata. Tesis PS. Magister Kajian Pariwisata.Universitas Gadjah Mada. Yogyakarta.

Patusuri, Syamsul Alam. 2004. Perencanaan Kawasan Pariwisata, Modul Kuliah, Program magister Pariwisata. Bali.

Pendit. N. 1999. Ilmu Pariwisata Sebuah Pengantar. Perdana. Jakarta.

Rangkuti, F. 2001. Analisis Skala Likert Teknik Membedah Kasus Bisnis, Penerbit Gramedia Pustaka Utama, Jakarta. 
Selo Soemardjan, 2000. Perubahan Sosial. Grasindo. Jakarta

Sjafri Sairin, 2012. Perubahan Sosial Masyarakat Indonesia: Prespektif Antripologi. Pustaka Belajar. Yogyakarta

Soebagyo, 2012. Sektor Pariwisata, Penerbit Gramedia Pustaka Utama, Jakarta.

Soelaeman, M. 2005. Perubahan Sosial Menurut Ahli. Refika Aditama. Bandung.
Susanto, Phil, Astrid. 2000. Pengantar Sosiologi dan Perubahan Sosial. Bina Cipta. Bandung.

Taneko, 1999. Integrasi Sosial dalam perubahan sosial. http;//www. artikelsiana.com/2015/08/download diakses tanggal 5 Oktober 2015.

Tirtawinata, M.R.F, Lisdiana, 1996. Daya tarik dan pengelolaan pariwisata, deskripsi fisik, Jakarta. 